\title{
"Put a Stop to the Excessive Influx": The Rhetoric of Restriction Regarding Female and Jewish Students at Budapest University, 1900-1930
}

\author{
Anna Borgos, Institute of Cognitive Neuroscience and Psychology, Hungary
}

ABSTRACT | The idea of a numerus clausus at Hungarian universities was first directed against female students, the majority of whom were of Jewish origin. This intersectional study of the justifications articulated in favor of restricting the university admission of Jewish and female students highlights the shifting political and social ideas of the period. Based on archival and press sources, and drawing in particular on the faculty council minutes of the Faculties of Medicine and Humanities at Budapest University, this article explores both the common and distinct features of the rhetoric directed against female and Jewish students, respectively, and focuses on the interconnected interests and fears regarding the two social groups.

KEYWORDS | numerus clausus, Hungary, women, Jews, higher education

The social position of Jews and women has changed considerably over the course of the modern era, in both positive and negative directions. In Hungary, as in other modernizing nations in Europe, the nineteenth century saw a gradual widening of social and professional opportunities for both groups, though by the fin de siècle, both Jews and women also became targets of intensifying and often new forms of prejudice and exclusion. One common domain of inclusion and exclusion for both groups was higher education. By the beginning of the twentieth century, an increasing number of Jews and women had found a place for themselves in universities and advanced institutions of higher learning, and Hungary was no exception to this broader European trend. Hungary's numerus clausus law, however,

doi: 10.5325/hungarianstud.48.1.0048

Hungarian Studies Review, Vol. 48, No. 1, 2021

Copyright (C) 2021 The Pennsylvania State University, University Park, PA 
marked a drastic reversal of these otherwise progressive developments. Enacted in 1920 to alter and "nationalize" the student body in Hungarian universities, the numerus clausus resulted in the dramatic reduction of female and Jewish students in universities in Hungary during the interwar period. Their parallel story is the subject of this article.

The history of the restriction of Jews and women in Hungarian higher education has been the subject of a few notable studies, some of which have discussed these histories in relation to each other. Published in 1988, Katalin N. Szegvári's groundbreaking book Numerus clausus rendelkezések az ellenforradalmi Magyarországon: A zsidó és nőhallgatók föiskolai felvételéröl [Numerus clausus provisions in counter-revolutionary Hungary: on the college admission of Jewish and female students] was the first major Hungarian study to tackle the intersecting question of Jewish and female exclusion from Hungarian higher education in the interwar period. ${ }^{1}$ More recent studies like Katalin Fenyves's "When Sexism Meets Racism: The 1920 Numerus Clausus Law in Hungary," ${ }^{\text {as }}$ well as Michaela Raggam-Blesch's work on the similar experiences of Jews and women in Vienna, ${ }^{3}$ have further emphasized not only the ambivalent social, cultural, and political attitudes toward assimilated Jews and female students during this period but also the increasingly exclusionary policies that affected them, especially after World War I. However, although important studies like these have considered the parallel histories of both groups in relation to each other, for the most part the histories of women and Jews in Hungarian universities and research institutions in the first half of the twentieth century are treated separately. ${ }^{4}$ Perhaps more notably, what these studies have thus far neglected are the common motifs mobilized by nationalist politicians, publicists, and scholars to reduce the presence of both groups in Hungarian higher education.

Focusing on Budapest University (which after 1921 became the Hungarian Royal Péter Pázmány University), and relying primarily on the minutes of faculty councils of the Faculty of Medicine and the Faculty of Humanities as the main primary resources, my study reflects on the parallel histories of the educational rights of Jews and women between the 189os and the 1920 . Looking primarily at the views of the university leadership, politicians, and the press, I will explore the rhetoric that both reflected and reinforced shifting attitudes toward the two groups. Through a close reading of texts and speeches that addressed the issues of Jewish and female students between the late nineteenth century and the early decades of the twentieth, this article 
reveals important connections between Jewish and female exclusion that have been less studied and that demonstrate the political and social ideologies of the era especially well. As my study will lay out, these discourses illuminate the similarities between arguments and attitudes directed toward Jews and women, as well as the underlying fears and ideas about who should, and especially who should not, become a member of the intellectual middle class.

\section{Jewish and Female Students}

Between the two world wars, nationalist and political antisemitism increased all over Europe. It was both the indicator and the consequence of political, social, and economic crises. In Hungary, World War I and its loss, which was followed in quick succession by the dissolution of the Austro-Hungarian Monarchy in 1918, the short-lived Communist regime of the Republic of Councils in 1919, the national trauma of the punitive Trianon Treaty in 1920, and the violent counter-revolution that followed in the wake of Hungary's postwar revolutionary transformations, brought about a great deal of existential uncertainty and anxiety. The apprehension and unease of the period resulted in an escalating hostility toward "strangers," a phenomenon that Roger Griffin has characterized as a kind of splitting regarding those considered to be "others." In this context, loyalty to the nation became a key issue, and although they had long been embedded in Hungarian society and had already enjoyed citizenship rights and religious emancipation for decades, the rising xenophobia and scapegoating were directed mostly against Jews.

The roots of this antisemitism were complex. In the image of the Jews, a set of anxieties and often contradictory projections met: those of the economically influential capitalist versus the politically dissident communist; the skillful materialist versus the hysterical feminine; ${ }^{6}$ and the religious stranger versus the assimilated citizen whose racial origin was not visible (thus rendering the Jewish individual all the more "dangerous"). Denominational anti-Judaism had increasingly become political antisemitism at the state level by the turn of the century, and even more so after World War I. ${ }^{7}$ From this perspective, the 1920 numerus clausus law can be seen as the "rationalization of the nationalist demonization of Jews."

Looking at the international context, university quotas were prescribed during this period in several institutions in other countries, including Norway, Finland, and Scotland; however, it was nowhere coupled with such 
system-wide racial or gender discrimination. Anti-Jewish quotas were also introduced in a few universities in the United States and Canada, for example, but these did not rise to a state or statutory level, so students could go on with their studies at other universities where quotas had not been introduced. ${ }^{9}$ Within Central Europe itself, political and everyday verbal and physical antisemitism began increasing from the 1910s. As in Hungary, the numerus clausus was on the agenda in the 1920 s in Austria, Poland, Czechoslovakia, and Romania as well, and though some universities applied it on an institutional level (for example, by seating Jewish students in segregated seats), it was not applied or enforced by law until the $1930{ }^{10}{ }^{10}$ In this sense the Hungarian numerus clausus law enacted in 1920 was exceptional for its time.

Up until the numerus clausus law was implemented in $1920,{ }^{11}$ Jewswho constituted only 6 percent of the total population of Hungary-were significantly overrepresented at universities, both for historical and cultural reasons (more on this below). In 1920, 13 percent of Hungarian intellectuals with a university education were of Jewish origin. However, as Mária M. Kovács has pointed out, 75 percent of Jews in Hungary were city dwellers (25 percent of the inhabitants of Budapest and 13 percent of other cities were Jews); considering this population, and given that urban people in general were overrepresented in higher education, their university presence was not extraordinarily high. At the same time, whereas the proportion of Jews among merchants, physicians, lawyers, journalists, and artists was nearly 50 percent, their presence in public service or in the teaching profession was by no means high. ${ }^{12}$

As far as women were concerned, until the end of the nineteenth century, the principal issue was not so much the proportion of female students as part of the general university population but rather the question of admission itself. The struggle for and debates on women in higher education had intensified from the second half of the nineteenth century, ${ }^{13}$ and they subsequently grew in strength from the early 1910s. The debates also reflected the emergence and transformation of feminist movements, in particular as university admission for women (as well as women's work and suffrage) became one of the main fields of feminist struggle. ${ }^{14}$ Though the arguments and counterarguments surrounding the admission of female students would change slightly after the (partial) opening of universities to women in 1896 , some motifs, such as the question of women's suitability 
for certain fields of studies, remained constant. The level of acceptance also depended on the profession that the given university provided access to (the medical faculties being much more exclusive and "defensive" of their prestigious profession than faculties of humanities). Historical and political circumstances (and especially World War I, the Republic of Councils, and the conservative turn of the 1920s) would soon have a clear influence on decisions made at the university and state level, which affected Jews and women similarly, at least in part.

One aspect that linked Jewish and female university students as social groups was the significant overlap between female and Jewish student populations during the first decades of women's entry into higher education. In the early 1900s, the proportion of Jews among female students at Budapest University in some years approached close to 50 percent, though in the immediate period leading up to the implementation of the numerus clausus law, it was around 40-45 percent. The proportion of Jews among female students was highest (50-60 percent) at the Faculty of Medicine, while at the Faculty of Humanities and the Faculty of Pharmacy it was 30-35 percent. ${ }^{15}$ The proportion of Jewish women among female students was higher when compared to the percentage of Jewish men among male students. In 1910 that was 38 percent versus 21 percent, and in 1914 it was 42 percent versus 35 percent. ${ }^{16}$ This difference persisted even after the introduction of the numerus clausus law, which adversely affected female students more than Jewish male students, if on a different scale. ${ }^{17}$ The female student body in general was also characterized by other significant factors. In addition to having a higher representation of middle-class city dwellers of good social circumstances, female students tended to perform better than their male counterparts (in large part because of the stricter admission requirements for women than for men, such as an excellent high school diploma [jeles érettségi]) and also entered university with considerable cultural capital (for example, an ability in languages and music and a greater experience with "cultural consumption"). As Victor Karady notes, this phenomenon can be characterized as one of "intellectual overselection." ${ }^{18}$ Female students therefore had a more homogeneous social background than male students: most of them came from intellectual or civil-servant families or were daughters of parents working in industry and commerce. ${ }^{19}$ At the same time, during their university years many of them struggled with financial and housing difficulties as well as with limited earning opportunities. 
As for the sociocultural reasons for the high representation of Jews among women at the universities, several factors played a role. On the one hand, modernization (which included urbanization, industrial development, and the transformation of the feudal social system and its stratification) made intellectual capital more accessible to women in general, a process that was itself facilitated largely by feminist movements. This affected first the better-off and more educated strata, where families were able and willing to make this long-term cultural "investment," often through the daughters. On the other hand, rapid secularization and rising emancipation in terms of religion and gender roles had an increased effect among Jews as a social group with high (or forced) social mobility. Jews also had a stronger desire for a partner with a similar education (and strongly valued studying in general), as well as greater openness to Western, modern, civic female models and lifestyles compared to the Christian middle class, which remained more attached to traditional family and gender roles. ${ }^{20}$

The other historical connection between the restriction of female and Jewish students is quite direct, as the idea of the numerus clausus at the university was first raised with regards to female students. ${ }^{21}$ In August 1919, the Medical Faculty of Budapest University made a proposal to temporarily suspend or restrict the admission of women, a recommendation that was implemented soon after. Between 1920 and 1926, the Medical Faculty in fact applied a numerus nullus to women. Of course, the principle of "two birds with one stone" was clearly visible and articulated. The overlap between female and Jewish students was explicitly recognized at the meeting of the University Council in December 1919, already in connection with a restriction based on ethnic origin. As the minutes of the December 4 University Council meeting recorded, "it is obvious that in the case of the [ethnic] numerus clausus, the proportion of female students could be fixed without any theoretical or practical difficulties."22

Apart from the treatment of Jews and women as a "common set," similarities can also be found in the decision-making mechanisms, motives, intentions, arguments, and background of hate and fear toward Jewish and female students. Antisemitism and anti-feminism are often associated, and their roots are in part similar, or, rather, are common indicators of the mechanisms of exclusion and "defense" of a society. In this context, the university was a symptomatic space with both symbolic and practical significance, reflecting and shaping attitudes toward a marginalized group. 


\section{Women at the University: Openings, Barriers, and Opinions}

In 1896 , following the 1895 decree issued by Gyula Wlassics, ${ }^{23}$ the Minister of Religion and Public Education, three university faculties $(\mathrm{Hu}-$ manities, Medicine, and Pharmacy) were opened to women in Hungary (similar openings occurred in Austria and Germany at about the same time). The text of Wlassics' ministerial order represents very clearly the transitional situation of women. The decree expressed an attitude that was open to change and sensitive to inequalities, but that at the same time perceived women's gainful employment and qualifications in terms of "constraint," in that it provided reassurances regarding the conservation of traditional roles, as well as women's "vocation" and "virtues." ${ }^{24}$ As Wlassics indicated: "Changing social and cultural conditions have forced women to look for other livelihoods instead of the occupations they have held so far and to acquire the knowledge needed for this purpose. . . And who would not feel that the exclusion of the female sex from a part of scientific bread-winning paths with principled rigor is one of the great social injustices that will never be the glory of the bourgeoisie? . . The admission of women with considerable talent and inclination for scientific careers ... does not preclude the fulfillment of a woman's vocation, the preservation of women's virtues, and, in this connection, public morality. The vast majority of women continue to perform their task solely by fulfilling family duties." ${ }^{25}$

In the debates around women's access to higher education that were conducted in the university faculties, the press, and in parliament, the key word was "suitability." ${ }^{26}$ The liberal press was generally supportive. Opponents, however, typically wrapped their fears of change in worries about women's bodies, "mental constitution," and femininity. ${ }^{27}$ This was not a phenomenon particular to Hungary. Austrian philosopher Otto Weininger and German neurologist Karl Möbius are prime examples of influential public intellectuals whose misogynist preconceptions both represented and perpetuated general cultural stereotypes. Their views about the "abnormality of female scholarship" or concerns about the ability of female intellectuals to bear children were very similar to those that appeared in Hungary. So, too, was the general perception of femininity and intellectuality as opposed traits. ${ }^{28}$ According to comments made in 1898 by the medical professor Géza Mihalkovics, for example, learning "can result in the complete extinction of secondary sexual characteristics." ${ }^{29}$ It is important 
to note that anti-feminist views were not exclusive to the politically conservative side. According to an 1899 parliamentary speech by the Liberal Party MP and physician Samu Pap, women who pursued higher education would "lose all external signs of their femininity and turn into unidentifiable beings."30

Philosopher Gyula Kornis (who from 1927 to 1931 served as Secretary of State for Public Education under Minister of Religion and Education Kunó Klebelsberg) devoted several studies to the issue, summarizing practically all the concerns and stereotypes regarding women's higher education. According to his thesis, "the female body is unsuitable for strenuous mental activity" because of the "over-emotionality, subjectivity, aversion to abstraction, and dependence inherent in the female constitution." ${ }^{31}$ He believed that this educational effort was not really desired by women either, and that they suffered from it physically as well. "Most women," he wrote, "feel intensive learning a constraint because their natural tendencies are in a different direction. Strenuous mental work is unfavorable for physical development (just observe the skinny-pale, physically undeveloped, neurasthenic maidens in a girls' high school graduation examination!) ... the end is premature withering, like a lily dying (liliomhullás)." ${ }^{32}$ Women's learning, he asserted, was a fashion coming from America, and was a station on the road to "female domination." "Universities must be open to aspiring and fit women within the indicated framework. But women's university studies should not be a trend.... In America in 1910, 430,000 women and 828,000 men were pursuing an intellectual career. There, female domination, gynocracy, has become almost a dogma, as $\mathrm{H}$ [ugo] Münsterberg, the great psychologist, says." ${ }^{33}$ Kornis examined the various intellectual fields and found that women were unfit to pursue virtually all of them. He declared that the medical career was "inconsistent with women's natural physical and mental constitution" and that patients had no confidence in them either (he generously allowed them the possibility of studying pharmacy, however). Women were not recommended for positions as engineers or professors either, though he was willing to make a few exceptions for those in possession of "masculine intelligence."

The legal profession was a particularly delicate point, as it was obviously also a matter of power; at stake was the potential to influence the affairs of the public sector, and the state. This appeared openly in Kornis's writing, too, as he portrayed the apotheosis of patriarchy as an order of "nature." 
"The doctor does only private work, but the legal career is a matter of the imperum and jurisdictio, and as long as the state remains a male state (as it has been for so many millennia), it will not easily give these two into the hands of women. ... Even without men's conscious aspiration for power, it is a natural state, the division of the roles of men and women according to the order of nature. This is essentially not a 'power' issue, but a historically proven fact of correct complementarity." 34

A poll in the 1906 Christmas issue of the newspaper $A z$ Ujság focused on the admission of women to the faculties of Law and Engineering. ${ }^{35}$ The inquiry demonstrated the typical standpoint that, while doctors found women more suitable for the legal career, lawyers found them more suitable for medicine. The respondents to the poll were presumably motivated by the desire to restrain female colleagues from generating competition in their own profession.

Various "moral" concerns appeared as well in the debates over women's admission to the university, with warnings that men and women learning together may lead to dangerous, unwanted relationships; women, it was thought, would distract men's attention from science and would become immoral themselves. An anonymous article published in Egyetemi Lapok [University Papers] on December 2, 1895 saw the opening of the university as a direct path to prostitution. Written presumably by a professor, the article claimed, "The higher women's literacy is, the freer their thinking is ... and the flightier their morals are. And if every woman becomes a scholar, then it will not be 30,000 women in Budapest selling love, but all of them." ${ }^{36}$ According to another author's sarcastic characterization, female students were recognizable just by their sour expression and apparent disregard for their outer appearance: "In today's society, women university students are a very separate group that the world looks at with some kind of amazement. Although for about twenty years they haven't been wearing eccentric clothes like they used to, they can still be recognized for their elongated faces and total contempt for flirtations and vanities."37

Of course, worries about the "natural" primacy of the family and maternal vocation were also recurring. In his 1915 article published in Nemzeti Nónevelés [National Women’s Education], the geologist Elemér M. Vadász declared that "this effect is manifested in the freedom of conversation, in the decline of femininity. And since, in spite of their university studies, the goal of all women can only be marriage, the question is whether the 
diminished glaze of their femininity is in this respect beneficial. ${ }^{38}$ More than a decade earlier, the journalist and cultural historian Aladár György had pointed out the hypocrisy of this line of argumentation. As he wrote in the same journal in 1901, opponents to female admission to the university saw the misery of factory workers, widows, and orphans to be compatible with traditional (patriarchal) "family happiness" and the "feminine constitution," yet felt these virtues were being endangered by a few hundred university students. ${ }^{39}$

In his January 1907 parliamentary speech, Károly Kmety, an Independence Party MP and professor of law, contended that the new roles of women were not in line with the liberal worldview: "I do not consider it a requirement of liberalism ... that girls be taken out of their natural vocation.... I express my concern that the number of female students is greatly increasing. . . . Won't the inevitably emerging graduate female proletariat bring us more trouble?" He perceived the new type, called "female monsters," such a threat that he put the responsibility for a potential national catastrophe on their shoulders: "If national life in Hungary starts to perish, we will owe it to this . . female type." ${ }^{40}$ Rózsa Bédy-Schwimmer, the president of the Association of Feminists (Feministák Egyesülete), responded to the speech in a vitriolic editorial in the then newly-launched magazine $A$ Nó és a Társadalom [Woman and Society]. Already using the term numerus clausus, Bédy-Schwimmer wrote, "Kmety asks for a numerus clausus against female students at the university. Bánffy ${ }^{41}$ goes further and believes that, on the issue of women's education, the minister should take a position of restriction not only at universities but already at high schools. If the budget were not so urgent, there might possibly appear some friends of darkness who would glorify women's lack of education as a national virtue at the level of primary education and even kindergartens." ${ }^{2}$

The first attempts at restriction on the part of the university faculties had already appeared as early as 1903. Gusztáv Heinrich, professor of literature at the Faculty of Humanities of Budapest University (and the brotherin-law of Wlassics) proposed to determine the conditions for the admission of female students. The report of the Faculty of Humanities commission claimed that the university should recruit only eminently talented women, in order to prevent the "mass influx" of female students. ${ }^{43}$ The University Council also took the stance of "preventing women's unjustified influx into scholarly careers." ${ }^{44}$ As a result of the corresponding ministry decree, from 
1904 onward, both at the Faculty of Humanities and the Medical Faculty, women could become regular students only if they had graduated with an excellent high school diploma; they also had to apply to the minister for admission. Protests began in response to the action taken by the two faculties, and in December 1904 the Association of Feminists was formed, which in the following years made several submissions to expand higher education. By contrast, Keresztény Magyar Ifjúság [Christian Hungarian Youth], a magazine of conservative university students, justified to its readers the provisions being proposed by the University. "The number of female students," the magazine stated, "has already reached terrible proportions this year." 45

From 2 percent at the turn of the century, the proportion of women in the Faculty of Humanities in Budapest University rose to 25 percent by the beginning of the 1910 (it was around 5 percent in the Faculty of Medicine). The impact of World War I, in turn, was decisive for the transformation of women's roles and the proliferation of women's work, and also involved a significant rise in the proportion of female students. In 1918, this proportion was already 52 percent in the Faculty of Humanities and 28 percent in the Faculty of Medicine. The first female teaching assistants were also appointed during this period. Erzsébet Hamburger was appointed at the Faculty of Medicine (Department of Pharmacy) in 1910, and Eleonóra Harmos at the Faculty of Humanities (Department of Geography) in $1915 .{ }^{46}$

In April 1915, at the initiative of humanities students, 242 female students issued a memorandum requesting the lifting of restrictions against women. Supported by the Faculty of Medicine of Budapest University, the ministry nevertheless set the matter aside. ${ }^{47}$ On the proposal of Bernát Alexander, dean of the Faculty of Humanities, the university council also discussed the issue shortly afterward. In his speech, he pointed out, among other things, the untenability of prejudice in the university's policy: "It is certain that women, with their supposedly lesser talent, outdo men and learn exactly what they need to know, while men, with all their genius, fail en masse." 48 According to the statistics, women's examination scores were indeed better, a fact that was partly due to the more rigorous selection criteria outlined above, and partly (and presumably) due to greater effort on their part.

In December 1915, the influential left-wing students' society, the Galileo Circle, called for the opening of all faculties to women. Though they had 
the support of several professors, their demand was ineffective. In July 1917, female university students applied again to the ministry for the opening of all faculties; the ministry then sent their appeal to the universities for comment. In his report, Dean Ignác Goldziher conveyed the conservative position of the Faculty of Humanities at Budapest University. "Overflow" had become a cause for serious concern, and beyond the problem of seats, university leaders were also worried about the seriousness and prestige of the institution: "Today's state of affairs, which has been induced by the mass influx of female students, brings about a legitimate concern ... for all those who take university education seriously.... We are not led by any animosity toward female students; with good-natured sympathy, we look at the struggle they face, first of all, with the difficulties of studying at a university and then with the obstacles in their professional careers, the struggle of which, unfortunately, mostly results in their premature withering and the draining of their capacity for work! ... The university is a men's institution. ... If the current flood continues to increase ... the student youth will not fit in our lecture halls and some kind of numerus clausus will have to be implemented." 49

Goldziher argued that the faculty should definitely reject the proposal to allow women to be admitted as special students (rendkivüli hallgatók) ${ }^{50}$ from the age of sixteen (just as men could be), thus devaluing the abilities and ambitions of potential female students. As he stated in an indignant and ironic way, "access to university would be almost as easy as to a theater or a cinema; what a female audience we would get here-one that would make any scientific work illusory anyway." He suggested that opening the other faculties would be beneficial to the Faculty of Humanities, inasmuch as it would divert some of the female students "to institutions where they might be more appropriate." It is not clear where he thought women's place was "more appropriate," however. ${ }^{11}$ Typically, each faculty found the others more suitable for women.

The situation was not necessarily better for women who were directed into the fields of art and music. In a letter written in March 1917, Béla Bartók (who in the late 1930s would protest against the anti-Jewish laws) expressed reluctance toward his private students, both as women and Jews: "All [12] are girls and, with the exception of one, all are Jewish.... And they are all private students. Isn't it awful, to take care of so many Ellas, Erzsis, and Lilis, and feed them all."52 
In the journal of the Association of Feminists ( $A$ Nö [The Woman]; originally A Nó és a Társadalom [Woman and Society]), the poet Géza Szilágyi and the mathematician Manó Beke refuted prejudices and supported the full opening of universities to women..$^{53}$ The Association of Feminists in 1912 and the National Alliance of Hungarian Women (Magyar Asszonyok Nemzeti Szövetsége-MANSZ) in 1917 requested the opening of legal faculties for women. Professor of Law Gusztáv Szászy-Schwarz supported the request, and so in 1918 the faculty temporarily admitted female students, and some women lawyers graduated. ${ }^{54}$ In November 1917, Albert Apponyi, Minister of Religion and Public Education, made a proposal to the King to open all university faculties and academies of law. There was no answer to this, and his successor, János Zichy, subsequently considered the matter no longer urgent. From 1918 onward, however, Hungary's economic academies as well as the Reformed theological academies accepted women. ${ }^{55}$

After the liberal "Aster Revolution" in 1918, left-wing students and social organizations began demanding that university faculties be opened unrestrictedly to women. The female special students of Budapest University also demanded in a memorandum to lift the admission restrictions. In the fall of 1918, the Galileo Circle prepared a plan for higher education reform, part of which was to provide women with equal access to all faculties and departments. The Károlyi government accepted the proposal, and thus for a short time all universities opened to women without restrictions. ${ }^{56}$ This decree remained in effect during the Communist Republic of Councils in 1919 as well and was only altered by university faculties after 1920, as will be detailed in the next section.

\section{The Women's Numerus Clausus}

As Szegvári, Fenyves, and Kovács have all pointed out, much like the evolving negative attitude toward Jews, the perception and public response to emancipated women had become more critical by the late $1910 .{ }^{57}$ Women's growing access to higher education at the turn of the century and in the 1910s, coupled with the influence that World War I had on extending women's social roles, was followed by a significant backlash against women's emancipation in the 1920s-which was represented in the feminist movement as well. Alongside the legislated racial quota imposed by the numerus 
clausus, the pre-1918 limitations on women's educational rights were also restored.

The collapse of the Republic of Councils on August 1, 1919 was followed by violent, overtly antisemitic reprisals and by the cancellation of the decrees and appointments that had been implemented during the Communist period. The conservative turn imposed drastic restrictions on women's access to education as well. By the end of 1919, the proportion of female students fell by almost half. At Budapest University, women constituted only 12 percent in the Faculty of Medicine, and 33 percent in the Faculty of Humanities. Until 1918, members of the Medical Faculty (for example, Ernő Jendrassik and Emil Grósz) had been especially supportive of female students, but from the 1920s the anti-feminist and antisemitic Károly Hoór and János Bársony became prominent figures at the university. In August 1919, the Medical Faculty made a proposal to temporarily suspend and then restrict women's admission: female students needed to be a minimum of twenty-two years old and have a high school diploma of excellent qualification, which meant having achieved the best final grade in all subjects of the finishing exam..$^{58}$ Although the "general disappointment" and exhaustion of female doctors was emphasized, the main argument was the "existential competition" caused by the emergence of women physicians. To quote Károly Hoór, "During the war, women took the place of the soldiers; in the absence of male contenders they became assistant professors, got important and lucrative jobs, and got ahead of their male colleagues. It became an urgent duty to prevent mutilated Hungary from being inundated with female doctors, that is, with doctors being definitely, and in all respects, less valuable compared to male doctors." ${ }^{\text {99 }}$ According to Szegvári, the perception of an increasing "intellectual proletariat" in fact justified the resurgent religious and gender discrimination and exclusion. ${ }^{60}$

Conservatives very much saw the presence of women in the university and in intellectual professions in terms of a "takeover," one that required them to be on the "defensive." The rhetoric that they employed strongly evoked the discourse of the numerus clausus directed at Jews. The rhetorically declared goal was not exclusion, but rather "defensive struggle" ${ }^{\text {"1 }}$ in both cases (in the case of Jews, a further slogan was "proportionality" In September 1919, Ernő Fináczy, the dean of the Faculty of Humanities of Budapest University (who would later protest against the numerus clausus law), noted that although women did not disappoint in the teaching 
profession, many were enrolled in the university without "physical and mental aptitude" and without a "true sense of vocation." ${ }^{63}$ In the end, he fell short of calling for a complete exclusion of women from the university, suggesting instead that enrollment be limited to female students who were at least twenty-one years old.

In December 1919, Alfréd Doleschall, dean of the Faculty of Law, made a more drastic proposal, calling for the postponing of enrollment and the introduction of a numerus clausus for women. The Medical Faculty proposed that, until the "mass shifts [that] appeared during the war in favor of women equalize," the faculty should not admit any more female students and even after that only women above the age of twenty-two. ${ }^{64}$

Doleschall's proposal is particularly noteworthy as, in addition to gender discrimination, the "racial" aspect first appeared in its wake. Writing in support of Doleschall's recommended restrictions, Mihály Kmoskó, dean of the Faculty of Theology, proposed a numerus clausus "by religion, progress, and race" in each faculty. The Faculty of Humanities agreed that, in general, it would be necessary to set limits and to admit nationally loyal and reliable students, although it would be difficult to realize this in practice. However, the faculty did not support a racially based numerus clausus, "since, according to our basic state laws, all citizens of the Hungarian state have equal rights before the law without any difference in denomination or nationality."65 They were also relatively liberal regarding women: although they regretted that the Károlyi government repealed the restrictions that existed before 1918, they also considered it illegal to restore them, and merely proposed an age limit of twenty-one years.

At an "extraordinary" meeting (rendkívüli ülés) of the Medical Faculty of Budapest University on September 25, 1920-that is, after the passing of the numerus clausus law-the issue of female students was put on the agenda. The two kinds of exclusion mutually reinforced each other. Professor János Bársony, one of the leading figures in support of racial and gender discrimination at the university (and rector after 1922), offered a specific religious-racial objection to women's admission, saying that female students would "displace boys, namely Christian boys." ${ }^{66}$ On the basis of Bársony's discriminatory initiative, numerus nullus was introduced; that is, the total exclusion of female students from the medical profession, a provision which remained in effect until 1926. Some women could go on with their studies at the medical faculties of Pécs, Szeged, and Debrecen, while 
others went abroad. Many of these women, however, were hindered in their university studies. ${ }^{67}$ The proportion of women in the medical faculties was reduced to around 8 percent in the 1920 .

In July 1920, Lajos Méhely (professor of zoology at Budapest University and advocate of racial biology and eugenics) submitted a report on the numerus clausus to the Faculty of Humanities. This report is one of the most horrific documentary examples of undisguised racism from the period. It also documents some of the parallels between the restrictions of women and Jews in the twisted rhetoric of "excessive influx." Stressing the need to "defend" the rights of Hungarian/male students and the "danger" of Jewification/feminization of the university, the report called on the university to preserve the prevailing (gender/"racial") privileges. Méhely believed that the earlier proposals had been too cautious and had avoided addressing the main point head on. By contrast, he did not mince his words: "Even if I did not say it, we would all know that one of the main, if not the only, aim and legitimacy of the numerus clausus is to prevent the excessive influx of Jewish students! . . . Here, with the sincere openness of the Hungarian soul, one must say that we strive to put a stop to the excessive influx of Jewish students with measures that are saturated with national spirit, but are sober and just. We do not in any way question the right of the Jews to send their sons [sic!] to university, but we demand the same right for the nation-maintaining Hungarians and other races and nationalities living in Hungary." Institutional constraint was essential, he added, "because following the current pace would lead to the complete Jewification of Hungarian universities." 68

Placing the issue in broader political context, Méhely referred to the unpredictable consequences of "rampant" liberalism. "We have to take it upon ourselves to see if we will preserve the unbridled liberalism that has run through all our institutions like a red thread since 1848 in the government of the university." As Méhely emphasized, Hungarian statesmen Loránd Eötvös, Gyula Andrássy, and Ottokár Prohászka also "pointed out the great national danger that has torn us from the unbridled liberalism of recent decades." Méhely proposed a 5 percent quota for Jewish students, but the question still remained whether baptized Jews should be included in this. Launching into a long racist and eugenic discussion about the relationship between religion and race, Méhely came to the conclusion that anthropologically and spiritually Jews remained Jews even after baptism. Moreover, 
under Mendel's rule, a "half-breed mongrel" is also Jewish. Such investigations had not yet taken place, he noted with regret, because then one would immediately be "labeled as antisemitic." He proposed a quota for women as well, limiting their enrollment to 5 percent of the total number of male students. Like many of his contemporaries, he also emphasized that female students should be a minimum of twenty-one years old and in possession of an "excellent" high school diploma.

\section{Conservative Women's Movements of the 1920s and the University Issue}

From the 1920 s on, the aims and rhetoric of women's movements changed in line with political ideology, and this turn significantly affected arguments both for and against women in higher education. From the 1920 s onward, MANSZ took over the representation of the interests of female university students from the feminists, and the issue of women's education (although it was also a fundamental issue for MANSZ) took on a nationalconservative direction and became increasingly a matter concerning Christian middle-class women.

In the spring of 1923, MANSZ and the women's branch of the National Association of Hungarian University and College Students (Magyar Egyetemi és Főiskolai Hallgatók Országos Szövetsége - MEFHOSZ) appealed to the faculties to cancel the female numerus nullus at the Medical Faculty of Budapest University and to open all faculties to women. ${ }^{69}$ In their justification, the two organizations emphasized not only economic and social-policy arguments but also the aspect of class. As they wrote, "the issue of women is fundamentally an economic issue," one that was rooted in the growing number of women whom men could not support. By limiting opportunities for learning and intellectual careers, middle-class women would be forced to renounce the social class that they were "born into"; they would become "declassed." In their basically feudal submission, the main argument was to maintain the economic and social status of young middle-class (that is, Hungarian Christian) girls.

The appeal by MANSZ and the women's branch of MEFHOSZ was written in a fundamentally different tone than the straightforward student submissions of 1915, or the earlier petitions of the Association of Feminists 
in 1911 and 1912. Here, "loyal" women with Christian-national affiliations appealed to decision makers with "daughterly confidence" in the interests of a "Hungarian resurrection." In their appeal, the "nation" emerged as a priority, and the issue of women's education was embedded in and subordinated to the Trianon trauma and the great issues of "national fate." "Young Hungarian girls," they declared, "have been silent for a long time; in the time of the great disaster that befell our country, it was not right to complain about our own problems. We thought that the country would not be able to deal with ... the questions of students or women until the millennial borders had been regained." ${ }^{\circ}$

While the text was not explicitly antisemitic-in fact it expressed some appreciation for the capabilities of Jews-it nevertheless formulated a clear distinction between Jews and Hungarians. Racist reasoning did not contradict (and in this case explicitly supported) women's rights: "It is Jews who produce the intelligentsia in the greatest numbers. The literacy of Jewish girls is higher than that of Christian girls, all the more so because (having the appropriate financial means) they have easy access to colleges in Germany, Vienna, or Prague, while to the poor Hungarian girls, if they are excluded from Hungarian universities, the world closes." ${ }^{11}$

Every faculty at Budapest University rejected the request. As Ernö Fináczy, dean of the Faculty of Humanities put it, "we have reached the limit of concessions." The issue was indeed a social one, as he admitted, but its solution was not opening up new careers but helping women "by protecting marriage and motherhood." The faculties, in turn, asked Gyula Kornis to study the matter and make a proposal. ${ }^{72}$

Kornis's proposal was ultimately published in 1925 in the form of an extensive study, "Women at the University," in the conservative journal Napkelet [Orient], which was under the editorship of Cécile Tormay, the head of MANSZ. I have already quoted Kornis's arguments about the "fitness" of women for study. This was accompanied by national and race-related concerns in women's scientific, or any bread-winning, career. "But all this is suicide for the race," he concluded. "Americans do not reproduce at all. ... Because women are self-employed, they take the jobs away from men, so the latter are less able to marry. The woman rises individually, but the warmth of family life disappears. . . The leading role of women in intellectual careers is more and more apparent in the image of public life too. It is beginning to lack strength and consistency." ${ }^{33}$ With both 
hypocritical and guilt-inducing rhetoric, he contrasted family/nation/race and existential independence: "What do I consider more valuable: family life and the resulting deep family and national solidarity and the health of the race or the abstract right of individuals to economic independence?"74

The study was answered by the conservative philosopher-writer Emma Ritoók and Marianne Czeke, the first female librarian in Hungary, who defined themselves as "non-radical feminists." 75 They pointed out that women had had the opportunity to work in scholarly fields for barely half a century, so the reference to historical examples was rather doubtful. Nevertheless, the authors did not question the priority of mother/family/nation over professional and material independence; their main argument was that these could be "reconciled." In the wake of Kornis's article-and with the support of MANSZ-The Association of Hungarian Women Graduates of University and College (Egyetemet és Főiskolát Végzett Magyar Nők Egyesülete) was established in 1925 by Czeke and Ritoók.

In 1928, an article by historian Ida Bobula was published in Napkelet. ${ }^{76}$ As she wrote, the "great collapse" and the loss of wealth reached the daughters of the Hungarian middle class "in their flowering years." A diploma would provide a livelihood for them, or at least knowledge. "Wissen ist Macht' [knowledge is power] is not just a phrase," she asserted. ${ }^{77}$ Moreover, the working woman would take the burden off the man. That is, she also believed that there was no conflict between the interests of the race and the rights of the individual in the issue of women's university studies; in fact, these supported each other. Furthermore, according to the author, it was "the ugly and the poor" who went to university, those who would have little chance of getting married anyway. The issue of women was couched in nationalist rhetoric in this characteristically conservative feminist stance, which left no doubt about the priority of motherhood: "We must recognize that the nation cannot be deprived of the female workforce that is de facto not occupied by the most sacred profession of motherhood and the managing of the household. We need to recognize that reorganizing the female workforce in the spirit of the age is one of our biggest and most vital national tasks." ${ }^{78}$ Jews also came up in the article. Bobula pointed out that most of the first female students in Hungarian universities were of Jewish and German descent, noting that "their pragmatic cultural disposition helped them to recognize the utility of university studies earlier than others." "The problem," she added, "was that these first-generation students obviously could 
not gain the sympathy of the teaching staff." ${ }^{\prime 9}$ It is not clear from Bobula's formulation, however, whether the presumed antipathy of the professors was directed at the students because of their Jewish background, or because of their status as "first-generation" female students.

Finally, Klebelsberg's 1926 ministerial decree ordered the increased enrollment of female students at Hungary's universities and declared the exclusion of women from the medical profession illegal, as it prevented "those who have the inclination, the opportunity, and the ability to study." ${ }^{80}$ At the same time, however, he insisted that the "personal conditions" of the numerus clausus still needed to be met in terms of ethnicity and "political reliability." In the same year the Faculties of Protestant and Lutheran Theology, the Department of Economics, and (with a 5 percent quota) the Department of Architecture ${ }^{81}$ of the Technical University, as well as the agricultural and commercial majors in the Faculty of Economics, opened to women. Women continued to be excluded from the Faculties of Economics (with the exception of the above two majors), Law, and Political Science. ${ }^{82}$ In 1928, habilitation and thus an associate professorship also became possible for women. But in practice, (Christian) men continued to be favored.

Behind references to the "female constitution," or to "intellectual overproduction," biologization, or philosophizing, there were, in fact, vital social considerations and fears, particularly with respect to the rearrangement of the family and the social system, as well as shifting notions of gender and the challenge to power that came with increased female competition. Besides the recurring motives, the rhetoric changed according to the sociopolitical circumstances. In addition to "aptitude," with the opening of the university the terms "overproduction" and "influx," as well as the "protection" of the middle class, the family, the race, and the nation were frequently deployed by decision makers and also by the conservative women's movement.

In critical political-economic periods, it becomes especially apparent that "woman" is not a homogeneous social category. From the 1920s on, the fight for university access was waged not for the sake of all women, but rather for the daughters of the Christian-national middle class. Similar ruptures had already appeared around the issue of suffrage, too, mostly between the differing priorities of the socialist and bourgeois women's movements. As Szegvári has argued, from the 1920s, "equality was replaced by the program of 'class-appropriate' literacy." ${ }^{\prime 3}$ We could add "race-appropriate" 
to this assessment as well. The shift away from gender to race as the basis of discrimination coincided with the alignment of the conservative women's movement with a racialized form of nationalism, whose proponents sought to protect "Christian" Hungary from the so-called threat of Jews in the country's institutions of higher education and therefore in the state itself.

Starting in the 1930s, the heretofore similar trajectory of women and Jews in Hungarian higher education split: the proportion of female students stabilized (on average around 30 percent, at the Faculty of Humanities around 50 percent), while the proportion of female and male Jewish students decreased drastically to 5-6 percent, and in the early 1940s, after the introduction of more restrictive anti-Jewish legislation, to 2 percent. The meaning and consequence of the "intersection" of the two minority identities was transformed: Jewish female students were no longer excluded from education as women, but on the basis of their Jewish origin.

Although in 1934 the Minister of Religion and Public Education, Bálint Hóman, drafted a confidential announcement restricting female students to 30 percent, to improve the job prospects of graduates, this was not observed-in the Faculty of Medicine, their proportion was already below 20 percent; and in the Faculty of Humanities, as noted above, it remained well above 30 percent, at almost 50 percent. ${ }^{84}$ The exclusion of Jews intensified both inside and outside the walls of the university, taking increasingly direct forms with the introduction of anti-Jewish laws $(1938,1939,1941)$ and ultimately the complete deprivation of civil rights. A close reading of the texts relating to the numerus clausus thus makes it even clearer that the story of Jewish exclusion and persecution did not begin on March 19, 1944 with the German occupation of Hungary.

\section{The Experiences of Jewish Women}

For Jewish women intent on attaining a university education, the situation both before and after the passing of the numerus clausus was fraught with difficulties that emerged at the intersection of gender and ethnicity. Prior to World War I, for example, Jewish women - like female students in generalhad to negotiate the anti-feminist terrain of the university, even as opportunities began opening up to them and as voices emerged from inside and outside the institution to support their place in it. Faced with normative representations of both traditional and morally and culturally "appropriate" gender roles, 
female students and intellectuals had to deal with their own inner conflicts, a struggle that was made all the more challenging by the lack of role models. Some of them coped by being "gender-neutral" and by accomplishing more than the average in order to overcome stereotypes. As Raggam-Blesch shows in her study of the Viennese case, this was especially true for Jewish women, who tended to distance themselves not only from femininity and feminism but also from their Jewishness. ${ }^{85}$ In Hungary, the situation became even more complicated after World War I. Aggression toward Jewish students became more and more frequent during the 1920s, as did physical and verbal assaults against women. Female Jewish students were doubly affected by the antisemitic and misogynist atmosphere at the university, but overt discrimination was directed more at their Jewish background than at their sex. ${ }^{86}$

A brief overview of the individual experiences of three Jewish women helps to illustrate the nature of the struggles Jewish women in general faced with regard to gaining access to higher education in Hungary. Anna Pór (1913-2009), for example, the sister-in-law of Emmi Pikler, a renowned Hungarian pediatrician, was unable to earn a university degree at a Hungarian institution in the interwar period. After being refused admission as a Jew to all the Budapest universities, Pór studied eurhythmics (mozdulatmüvészet) in Budapest and dance and choreography in Paris. In her recollections she discussed her unsuccessful attempts to apply to Hungarian universities. "After high school graduation [in 1931], with my excellent high school diploma I applied to all the universities in the country for a degree in Hungarian literature, biology, and medicine, and I was rejected everywhere because the 'quota was filled." 87

The experiences of Alice Bálint (1898-1939), the eminent Hungarian psychoanalyst who had once dreamt about teaching at Budapest University, tell a similar, if perhaps even more poignant, story about the nature of exclusion in the counter-revolutionary period and about the antisemitic atrocities transpiring at the university. ${ }^{88}$ In her diary entry for August 19, 1919 (shortly after the fall of the Republic of Councils), she noted insightfully that "strangers" become threatening in times when the "basic tone" in society becomes precarious. For Bálint the events that were unfolding were simultaneously sad, tragic, and misguided: "The pogrom is going on at the university. You are firing a lot of good people now, but you will regret it later. My heart aches very much. I liked and wanted to be there. I wanted to work there. ... And now I have to leave.... Budapest culture was rootless 
anyway; the country as a whole won't miss it. It's not professors that are needed here but more production. There is no need for us. We are needed where culmination is achieved already, there they can bear strangers as they don't have to worry about the basic tone anymore." 89

The story of Erzsébet Kardos (1902-1945), a pediatrician and psychoanalyst killed by a Hungarian Arrow Cross squad in January 1945, sheds further light on the varied experiences of Jewish women in Hungary and on the lengths that some of them went to in order to achieve their educational and professional goals. Due to the restrictions on both Jews and women, Kardos studied medicine at the University of Würzburg between 1921 and 1923. There she also experienced antisemitism and therefore looked for other places to go. Unsuccessful, she finally came back to Hungary and finished her studies at the medical faculty of the Erzsébet University in Pécs, where numerus nullus was not applied to women and the numerus clausus was applied less strictly, especially to upper-year students. In a letter to a friend written from Würzburg in 1923, she anticipated the future: "Whatever happens, please have my passport extended and have Switzerland included. .. . I can anyway see that we must sacrifice the values we consider important in life and all the opportunity for what beauty it would provide perhaps for many a year to come, for something that is beyond our control, that people refer to as history." 90

As the ongoing research by Judith Szapor and Ágnes Kelemen into the life paths of Hungarian Jewish women after the numerus clausus shows, there is a clear need for further scholarship dedicated to the analysis and preservation of the memories of this group of Hungarian women..${ }^{91}$ Beyond conducting continued research on the way in which the Hungarian press framed the issue of Jewish and female inclusion and exclusion at the university, or studies on the literary representation of women and Jews in higher education, it would be desirable and indeed fruitful to collect and further analyze the personal recollections of and about Jews and/or women whose studies were hindered by discriminatory regulations or who were forced to study abroad. As the above cases suggest, women, and perhaps especially Jewish women, did not simply give up on their ambitions. Despite similar restrictions in other countries, some actively sought opportunities elsewhere, while others like Pór turned to alternative intellectual and/or cultural fields and professions (photography, eurhythmics, or psychoanalysis were some typical examples) that did not require a university diploma. 


\section{Conclusion}

Looking at the rhetoric of politicians, university professors, and the conservative women's movement around the issue of women's and Jews' admission to higher education, beyond the group-specific aspects, one can also notice a number of parallels. In the case of women, notions of "suitability" and "naturally given vocation" were obviously gender-specific-it would have been difficult to employ these arguments in regard to Jewish male students. At the same time, discourses about both groups were characterized by a kind of apologetic, self-justifying, scapegoating and evasive argumentation that mixed biological, economic, and political elements that referred to psychological constitution, national interest and defense, and survival of the race, underscoring the danger of intellectual unemployment and the displacement of both Christians and men. The apologetic and false nature of the arguments becomes obvious when we realize that the numerus clausus did not provide a "solution" to any of these perceived problems. Christian students did not storm the universities, and after the introduction of the law there was even a shortage of students. ${ }^{92}$ Women, moreover, did not "occupy" men's places; they just had more opportunities to study.

The actual goal, which was often concealed by the rhetoric but was sometimes overtly expressed, was to limit the number of Jewish and female graduates and intellectuals in order to strengthen the Christian-nationalist, politically loyal middle class, support "fitting" students and ultimately maintain the status quo of middle-class Christian men..$^{93}$ This agenda called for the drastic reduction of university admission for Jews, who were considered socially and "racially" harmful, and women, who were seen as threatening to traditional gender roles. As fellow targets in this story, the fate of women and Jews ran parallel, at least to the 1920s, while for Jewish women, who were doubly targeted, the experience was, as we have seen, even more complicated.

ANNA BORGOS is a psychologist and women's historian, working as a research fellow at the Institute of Cognitive Neuroscience and Psychology, Budapest. She holds a PhD in psychology from the University of Pécs. She is the editor in chief of the Hungarian psychoanalytic journal Imágó Budapest. With Ferenc Erős and Júlia Gyimesi she coedited the volume Psychology and Politics: Intersections of Science and Ideology in the History of Psy-Sciences, published in 2019 by CEU Press. Her book Women in the Budapest School of Psychoanalysis: Girls of Tomorrow is forthcoming from Routledge in 2021. 


\section{NOTES}

1. Katalin N. Szegvári, Numerus clausus rendelkezések az ellenforradalmi Magyarországon: A zsidó és nőhallgatók föiskolai felvételéről [Numerus clausus decrees in counter-revolutionary Hungary: on the college admission of Jewish and female students] (Budapest: Akadémiai, 1988).

2. Katalin Fenyves, "When Sexism Meets Racism: The 1920 Numerus Clausus Law in Hungary," Hungarian Cultural Studies 4 (2011): 87-102.

3. Michaela Raggam-Blesch, "Zwischen Antifeminismus und Antisemitismus: Jüdische Frauen an der Wiener Universität 1897-1938" [Between anti-feminism and antisemitism: Jewish women at the University of Vienna, 1897-1938], in Alma Mater Antisemitica: Akademisches Milieu, Juden und Antisemitismus an den Universitäten Europas zwischen 1918 und 1939 [Alma mater antisemitica: academic milieu, Jews, and antisemitism in European universities between 1918 and 1939], ed. Regina Fritz, Grzegorz Rossoliński-Liebe, and Jana Starek (Vienna: Wiener Wiesenthal Institut für Holocaust-Studien, 2016), 245-64; Michaela Raggam-Blesch, Zwischen Ost und West: Identitätskonstruktionen jüdischer Frauen in Wien [Between East and West: identity constructions of Jewish women in Vienna] (Innsbruck: StudienVerlag, 2008).

4. See, for example, Katalin N. Szegvári and Andor Ladányi, Nők az egyetemeken I: Küzdelmek a nök egyetemi tanulmányaiért [Women in universities I: struggles for women's university studies] (Budapest: Felsőoktatási Pedagógiai Kutatóközpont, 1976); Viktor Karády (Victor Karady), "A társadalmi egyenlőtlenségek Magyarországon a nők felsőbb iskoláztatásának korai fázisában" [Social inequalities in Hungary in the early stage of women's higher education], in Férfiuralom: Írások nőkröl, férfiakról, feminizmusról [Male domination: writings on women, men, and feminism], ed. Miklós Hadas (Budapest: Replika Kör, 1994), 176-95; Victor Karady and Péter Tibor Nagy, eds., The Numerus Clausus in Hungary: Studies on the First Anti-Jewish Law and Academic Anti-Semitism in Modern Central Europe (Budapest: Centre for Historical Research, History Department of the Central European University, 2012); Andor Ladányi, "Nők: Két évforduló; A nők felsőfokú tanulmányainak száz éve" [Women: two anniversaries; one hundred years of women's higher education], Educatio 5, no. 3 (1996): 375-89; Mária M. Kovács, "Numerus clausus Magyarországon: 1919-1945” [The numerus clausus in Hungary: 1919-1945], in Jogfosztás - 90 éve: Tanulmányok a numerus claususról [Disqualification-9o years ago: studies on the numerus clausus], ed. Judit Molnár (Budapest: Nonprofit Társadalomkutató Egyesület, 2011), 29-59.

5. Roger Griffin, "Politikai vagy ontológiai bizonytalanság? A modernitás szerepe a magyar antiszemitizmus megerősödésében a 20. század eleji Európában” [Political or ontological uncertainty? The role of modernity in the strengthening of antisemitism in early twentieth-century Europe], in Molnár, Jogfosztás, 13-26.

6. On the representation of Jews as "feminine" and the Jewish body in general, see Sander L. Gilman, The Jew's Body (New York: Routledge, 1991).

7. Paul Hanebrink, In Defense of Christian Hungary: Religion, Nationalism, and Antisemitism, 1890-1944 (Ithaca, NY: Cornell University Press, 2006).

8. Griffin, "Politikai vagy ontológiai bizonytalanság?", 24. All translations from the Hungarian are my own.

9. Mária M. Kovács, "Numerus clausus Magyarországon: 1919-1945.” 
10. See István Kovács, "A lengyel zsidóság helyzete a két világháború között” [The situation of Polish Jews between the two world wars], in Molnár, Jogfosztás, 292-99; Róbert Fiziker, “Hetz muass sein’: Antiszemitizmus a múlt század húszas éveinek Ausztriájában ["There must be a hunt": antisemitism in Austria in the twenties of the last century], in Molnár, Jogfosztás, 300-17; Hildegarda Pokreis, "A Komenský Egyetem zsidó hallgatói, 1920-1940" [Jewish students at the Komenský University, 1920-40], in Molnár, Jogfosztás, 318-26; Felicia Waldman, "A numerus clausus rögeszméje a 20. századi Romániában és az ezzel kapcsolatos jogalkotás” [The numerus clausus obsession in twentieth-century Romania and related legislation], in Molnár, Jogfosztás, 327-44. See also the studies by Konrad H. Jarausch, Grzegorz Krzywiec, Natalia Aleksiun, Zofia Trębacz, Raul Cârstocea, and Marija Vulesica (among others), in Fritz, Rossoliński-Liebe, and Starek, Alma mater antisemitica. On the development of antisemitism in Germany, see Shulamit Volkov, Germans, Jews, and Antisemites: Trials in Emancipation (Cambridge: Cambridge University Press, 2006).

11. The numerus clausus law (introduced in September 1920) limited the proportion of all non-Magyar nationalities among university students to 6 percent. The law clearly aimed at the reduction of Jewish students, as they were the only group that the law negatively affected. On the numerus clausus see Karady and Nagy, Numerus Clausus in Hungary.

12. N. Szegvári, Numerus clausus rendelkezések, 53; Mária M. Kovács, "Numerus clausus Magyarországon."

13. See, for example, Ildikó Müller, "Vélemények a nők felsőfokú képzéséről a dualizmus időszakában" [Opinions on the higher education of women in the period of dualism], in Nök a modernizálódó magyar társadalomban [Women in the modernizing Hungarian society], ed. Gábor Gyáni and Nóra Séllei (Debrecen: Csokonai, 2006), 223-39; Anna Fábri, Fanni Borbíró, and Eszter Szarka, eds., A nö és hivatása II: Szemelvények a magyarországi nőkérdés történetéböl 1866-1895 [The woman and her profession II: excerpts from the history of the Hungarian women's question, 1866-95] (Budapest: Kortárs, 2006); and Katalin Kéri, Hölgyek napernyővel: Nök a dualizmuskori Magyarországon 1867-1914 [Ladies with parasol: women in dualist Hungary, 1867-1914] (Pécs: Pro Pannónia, 2008).

14. See Dóra Czeferner, "A magyarországi feminista mozgalom első hivatalos lapja: A Nő és a Társadalom (1907-1913)" [The first official journal of the Hungarian feminist movement: Woman and Society (1907-13)], archívNET 19, no. 2 (2019), http://www.archivnet.hu/a-magyarorszagi-feminista-mozgalom-elso-hivatalos-lapja-a-no-es-a-tarsadalom-1907-1913.

15. N. Szegvári and Ladányi, Nők az egyetemeken I, 72; see also Péter Tibor Nagy, "Nemi esélyek a két világháború közötti bölcsészkarokon" [Gender chances in the humanities in the interwar years], in Bölcsészek és tanárok a 19-20. Században [Humanities students and professors in the nineteenth and twentieth centuries], ed. Zsuzsanna Hanna Bíró and Péter Tibor Nagy (Budapest: Wesley János Lelkészképző Főiskola, 2012), 106-11.

16. Karády, "A társadalmi egyenlőtlenségek," 181, 191.

17. In 1924, 13 percent of female and 8 percent of male students were Jewish. Karády, "A társadalmi egyenlötlenségek," 193. Data from the same period for the University of Vienna indicates that 26 percent of all female students, 20 percent of female humanities students, 48 percent of female medical students, and 38 percent of female law students were Jewish (foreign students are not counted in this data). Although there was no legal restriction in Vienna, the proportion of Jewish female students still fell by more than 50 percent compared to five years earlier; on this see Harriet Pass Freidenreich, Female, Jewish, Educated: 
The Lives of Central European University Women (Bloomington: Indiana University Press, 2002), 206. The proportion of female students was higher in Vienna than in Hungary. See N. Szegvári, Numerus clausus rendelkezések, 82.

18. Karády, "A társadalmi egyenlőtlenségek," 180-83. See also Nagy, "Nemi esélyek," 111-12; and Zsuzsanna Hanna Bíró, "A társadalmi nemek közötti különbségek a Horthy korszak bölcsészdiplomásai körében" [Gender differences among humanities graduates of the Horthy era], in Bíró and Nagy, Bölcsészek és tanárok, 161.

19. Ildikó Müller, “A Budapesti Tudományegyetem nőhallgatóságának társadalmi összetétele (1896-1914)" [The social composition of the female students at Budapest University, 1896-1914], Korall 3-4 (2001): 203-20.

20. See Karády, “A társadalmi egyenlőtlenségek Magyarországon," 183-87.

21. See Mária M. Kovács, "A magyar feminizmus korszakfordulója” [The turning point of Hungarian feminism], Café Bábel 1-2 (1994): 179-83; Mária M. Kovács, Törvénytől sújtva: A numerus clausus Magyarországon, 1920-1945 [Down by law: the numerus clausus in Hungary, 1920-1945] (Budapest: Napvilág, 2012); Fenyves, "When Sexism Meets Racism."

22. Minutes of the session of the university council, December 4, 1919, files of the Rector's Office, Eötvös Loránd University Archives.

23. A vallás- és közoktatásügyi m. kir. miniszternek 1895. évi 65.719. sz. a budapesti és kolozsvári egyetem tanácsához intézett leirata a nőknek a bölcsészeti, orvosi és gyógyszerészi pályákra léphetése tárgyában. [Announcement no. 65.719 of 1895 of the Minister of Religion and Public Education to the council of the universities of Budapest and Cluj-Napoca on the admission of women to the faculties of Humanities, Medicine and Pharmacy]. Published in A Nó és a Társadalom, 10, no. 2 (1916): 24-25. See also Fábri, Borbíró, and Szarka, A nö és hivatása II, 176-79.

24. Wlassics was asked to write about his decree 20 years later by the journal of the Association of Feminists, where he basically reinforced his decision regarding the opening but also argued for its "graduality." See Wlassics, “A nők a föiskolákon" [Women in the colleges], A Nö 12 (1915): 188-89.

25. Wlassics (1896), quoted by Fábri, Borbíró, and Szarka, A nö és hivatása II, 177.

26. For a collection of contemporary articles on this subject, see Fábri, Borbíró, and Szarka, A nö és hivatása II, 159-82. See also Müller, "Vélemények."

27. N. Szegvári, Numerus clausus rendelkezések.

28. Raggam-Blesch, Zwischen Ost und West; Raggam-Blesch, "Zwischen Antifeminismus und Antisemitismus."

29. Géza Mihalkovics, Rector's Inaugural Speech, September 25, 1898. Természettudományi Közlöny 30, no. 349 (1898): 561-84. Cited in N. Szegvári and Ladányi, Nők az egyetemeken $I, 34$.

30. Speech of Samu Pap in the House of Representatives, April 10, 1899. Cited in N. Szegvári and Ladányi, Nők az egyetemeken I, 35. The speech was answered by Vilma Hugonnai, the first Hungarian female doctor (a graduate of the University of Zurich in 1879), who declared: "Such claims are merely nightmares of veiled selfishness." See Vilma Hugonnai, "Nők az orvosi pályán" [Women in medical careers], Pesti Napló, April 16, 1899. Hugonnai's degree was not accepted by the Hungarian administration until 1897 , so until then she worked as a midwife. The first female doctor to graduate in Hungary (in 1900) was Sarolta Steinberger. On the history of women and medical studies in Hungary, see László Szögi, "A 
nők egyetemi tanulmányainak kérdése a budapesti orvostudományi karon 1896-1926" [The question of women's university studies at the Budapest Faculty of Medicine, 1896-1926] Orvostörténeti Közlemények 115-116, nos. 3-4 (1986): 139-42; Mária H. Péter, "Nők az egyetemen: Az első okleveles orvosnők és gyógyszerésznők a budapesti felsőoktatásban és a kolozsvári Ferenc József Tudományegyetemen" [Women at university: the first female doctors and pharmacists graduated from the Franz Joseph University in Kolozsvár (Cluj) and Budapest], Erdélyi Múzeum 80, no. 1 (2018): 137-51; Judit Forrai, “Orvosnők társadalmi és szakmai szelekciójának ontológiája: A kezdet” [The ontology of the social and professional selection of female physicians: the beginning] Kaleidoscope 10, no. 19 (2019): 32-58; Éva Bruckner, "Az első magyar orvosnők nyomában" [On the trail of the first Hungarian female doctors] Polgári Szemle 15, nos. 1-3 (2019): 381-98.

31. Gyula Kornis, "Nők az egyetemen II" [Women at the university II], Napkelet 3, no. 2 (1925): 181 .

32. Kornis, "Nők az egyetemen II," 181.

33. Kornis, "Nők az egyetemen II," 183.

34. Kornis, "Nők az egyetemen II," 178 (emphasis in the original). Compare Ervin Szabós supportive article from twenty years earlier: Sz. [Ervin Szabó], “A nők jogi studiumáról” [On women's legal studies], Huszadik Század 4, no. 2 (1903): 173.

35. Az Ujság, December 25, 1906.

36. Egyetemi Lapok, December 2, 1895. Cited in N. Szegvári, Numerus clausus rendelkezések, 63.

37. B. T., 1895. Republished in Fábri, Borbíró, and Szarka, A nő és hivatása II, 173-76.

38. Elemér M. Vadász, "Nők az egyetemen" [Women in the university], Nemzeti Nőnevelés 36, nos. 7-8 (1915): 287.

39. Aladár György, "Ne romboljátok szét a családi boldogságot! Előadás a Mária Dorothea Egyesület tanítónői szakosztályának 1897. Ülésén” [Don’t ruin family happiness! Lecture delivered at the 1897 meeting of the schoolmistress section of the Mary Dorothea Association], Nemzeti Nönevelés, 22, no. 1 (1901): 63-75, cited by N. Szegvári and Ladányi, Nők az egyetemeken I, 34. He also wrote on women in medical education. See Aladár György, "Nők mint orvosok" [Women as doctors], Nemzeti Nönevelés, 12, nos. 8-9 (1891): 441-44.

40. Cited in N. Szegvári and Ladányi, Nök az egyetemeken I, 44; and in Kéri, Hölgyek napernyövel, 120.

41. Dezső Bánffy was prime minister from 1895 to 1899 and then served as an opposition MP.

42. Rózsa Bédy-Schwimmer, "Női szörnyetegek" [Female monsters], A Nö és a Társadalom 1, no. 2 (1907): 17-18.

43. Minutes of the faculty council, session of September 21, 1903, Eötvös Loránd University Archives.

44. Cited in N. Szegvári and Ladányi, Nők az egyetemeken I, 39.

45. Keresztény Magyar Ifjúság, April 3, 1904, 10.

46. N. Szegvári and Ladányi, Nők az egyetemeken I, 74. The first Hungarian university professor was the chemist Irén Götz (1889-1941). Having graduated in 1911, she was first the student of Marie Curie in Paris for a year. She was appointed as a professor during the Republic of Councils, and emigrated in 1920. She worked in Cluj, Berlin, and from 1931 in 
Moscow, where she was imprisoned on fabricated charges in 1941. She was released from prison but died shortly after from typhus.

47. N. Szegvári and Ladányi, Nők az egyetemeken I, 58. Gyula Wlassics reacted to the students' request in the journal of the Association of Feminists, acknowledging its legitimacy and seeing confirmed his own decision from twenty years earlier regarding the (partial) opening. See Wlassics, "A nők a főiskolákon."

48. Session of the university council, June 25, 1915, 8.b.21. 2123/1914-15, Eötvös Loránd University Archives. Cited in N. Szegvári and Ladányi, Nök az egyetemeken I, 58; and in Müller, “Vélemények a nők felsőfokú képzéséről a dualizmus időszakában," 231.

49. Files of the Dean's Office, October 10, 1917, Eötvös Loránd University Archives.

50. Extraordinary or "special" students ("rendkívüli hallgatók") did not become university "citizens," and although they could attend classes and take exams, these semesters could not be counted when they were admitted as regular students. Nor could they receive a tuition exemption.

51. Files of the Dean's Office, October 10, 1917, Eötvös Loránd University Archives.

52. Cited in Péter Bihari, 1914: A nagy háború száz éve [The Great War one hundred years on] (Budapest: Kalligram, 2014), 388. On the history of women's higher education in fine arts, see Éva Bicskei, "Nők az országos magyar királyi mintarajztanoda- és rajztanárképezdében, 1871 és 1908 között” [Women in the National Hungarian Royal Drawing School and Art Teacher Training School between 1871 and 1908], in A Mintarajztanodától a Képzömüvészeti Föiskoláig [From the Drawing School to the College of Fine Arts], ed. Katalin Blaskóné Majkó and Annamária Szőke (Budapest: Magyar Képzőművészeti Egyetem, 2002), 223-42. http://www.mke.hu/mintarajztanoda/konyv2-07.htm

53. Géza Szilágyi, “Szomoru jubileum” [A sad jubilee], A Nö 2, no. 8 (1915): 124; Manó Beke, "Az egyetem megnyitása a nőknek" [The opening of universities to women], A Nő 3 , no. 2 (1916): 22-24; Manó Beke, "A főiskolák megnyitása a nőknek" [The opening of colleges to women], $A$ Nö 4, no. 9 (1917): 140-41.

54. Kornis, "Nők az egyetemen II," 175.

55. N. Szegvári and Ladányi, Nök az egyetemeken I.

56. Decree of Márton Lovászy, Minister of Religion and Public Education, December 7 , 1918. Cited in N. Szegvári and Ladányi, Nők az egyetemeken I, 83.

57. N. Szegvári, Numerus clausus rendelkezések; Fenyves, "When Sexism Meets Racism"; Mária M. Kovács, Törvénytöl sújtva.

58. Minutes of the faculty council, September 25, 1919, Semmelweis Medical University Archives.

59. Károly Hoór, A nők orvosképzése [The medical training of women] (Budapest: Centrum, 1923), 22.

6o. N. Szegvári, Numerus clausus rendelkezések, 46.

61. Ottokár Prohászka, "Elég volt-e?” [Was it enough?] (1918) in Iránytü: Összegyüjtött munkái XXII. [Compass: collected works XXII], ed. Antal Schütz (Budapest: Szent István Társulat, 1929), 189-93.

62. Alajos Kovács, A zsidóság térfoglalása Magyarországon [The Jewish occupation in Hungary] (Budapest: Kellner Nyomda, 1922).

63. Minutes of the faculty council, September 18, 1919, Eötvös Loránd University Archives. 
64. Minutes of the Rector's Office, December 4, 1919, Eötvös Loránd University Archives. 65. Minutes of the Rector's Office, December 4, 1919, Eötvös Loránd University Archives. 66. Minutes of the faculty council, September 25, 1920, Semmelweis Medical University Archives.

67. Based on the research of Judith Szapor, she and Éva Karádi have been assembling a database and are working on an exhibition about the impact of the numerus clausus law on women.

68. Minutes of the faculty council, July 5, 1920, Eötvös Loránd University Archives (emphases in the original).

69. Minutes of the Dean's Office, December 6, 1923, Eötvös Loránd University Archives.

70. Minutes of the Dean's Office, December 6, 1923, Eötvös Loránd University Archives.

71. Minutes of the Dean’s Office, December 6, 1923, Eötvös Loránd University Archives.

72. Minutes of the Dean's Office, February 8, 1924, Eötvös Loránd University Archives.

73. Kornis, "Nők az egyetemen II," 183. A similar line of argument was put forward by Károly Lechner, A női lélek és a feminizmus orvos-természettudományos megvilágításban [The female soul and feminism in medical-scientific light] (Budapest: Királyi Magyar Természettudományi Társulat, 1922). The position of the Catholic Church was conveyed by Ottokár Prohászka, “A házasságról” [On marriage] (1908), in Világosság a sötétségben: Pásztorlevelek, Összegyüjtött munkái IX [Light in the dark: pastoral letters, collected works IX], ed. Antal Schütz (Budapest: Szent István Társulat, 1928), 31-49.

74. Kornis, "Nők az egyetemen II," 184.

75. Emma Ritoók and Marianne Czeke, "Nők az egyetemen" [Women at the university], Napkelet 3, no. 5 (1925): 496-504.

76. Ida Bobula, "Az egyetemi nőkérdés Magyarországon" [The university women’s question in Hungary], Napkelet 6, no. 8 (1928): 581-95.

77. Bobula, "Az egyetemi nőkérdés," 592.

78. Bobula, "Az egyetemi nőkérdés," 595.

79. Bobula, "Az egyetemi nőkérdés," 586.

80. The minister's announcement is described in the minutes of the faculty council, September 7, 1926, Semmelweis Medical University Archives. Cited in N. Szegvári, Numerus clausus rendelkezések, 160.

81. On women's participation in technical higher education see Éva Vámos, “A nők részvételének megteremtése a tudományban és technikában Magyarországon - recepciók sorozata" [Creating the participation of women in science and technology in Hungary-a series of receptions], in A honi Kopernikusz-recepciótól a magyar Nobel-dijakig [From the domestic Copernicus reception to the Hungarian Nobel Prizes], ed. Gábor Palló (Budapest: Áron, 2004), http://www.phil-inst.hu/recepcio/htm/6/609_belso.htm.

82. See Béla Pukánszky, Fejezetek a nőnevelés történetéböl [Chapters from the history of women's education] (Budapest: Gondolat, 2006), 119.

83. N. Szegvári, Numerus clausus rendelkezések, 83.

84. See Ladányi, "Nők: Két évforduló," 383.

85. Raggam-Blesch, "Zwischen Antifeminismus und Antisemitismus."

86. Raggam-Blesch, "Zwischen Antifeminismus und Antisemitismus."

87. Recollections of Anna Pór, 2008. National Institute of Theatre History, Dance Archive, courtesy of Mátyás Pór J. and Éva Karádi. The quotation will be presented at the exhibition 
“Tanulni szerettek volna: A numerus clausus és a lányok" [They would have wanted to learn: the numerus clausus and the girls], curated by Éva Karádi and Judith Szapor, 2B Gallery, 2021.

88. Alice Bálint's husband, Michael Bálint, became a well-known analyst and theoretician in England.

89. Entry from Alice Bálint's notebook, August 19, 1919. Archives of the British Psychoanalytical Society, Alice and Michael Bálint's bequest.

90. Letter from Erzsébet Kardos to Ödön Bánki, Würzburg, 1923. Courtesy of Esther Bánki.

91. See also Ágnes Kelemen, "Peregrination in the Age of the Numerus Clausus: Hungarian Jewish Students in Interwar Europe" (PhD diss., Central European University, 2019).

92. See Mária M. Kovács, Törvénytöl sújtva, 28, 34, 150-54.

93. The status quo was also served by the 1928 amendment of the numerus clausus law and the introduction of the occupational quota. This, instead of "people's races," regulated the proportion of people belonging to different occupations, on the basis of the father's profession. The provision continued to disadvantage Jewish students, favoring the children of civil servants and those working in agriculture, where the proportion of Jews was traditionally lower. See Mária M. Kovács, Törvénytöl sújtva, 200-201. 